\title{
PERAN PENDIDIKAN KEWARGANEGARAAN DALAM MEMBANGUN WARGA NEGARA GLOBAL
}

\author{
SUTRISNO \\ Staf Pengajar Prodi PPKn FKIP Universitas Muhammadiyah Ponorogo \\ Email: sutrisno@umpo.ac.id
}

Naskah diterima: 07/12/2017 revisi: 03/01/2018 disetujui: 23/04/2018

\begin{abstract}
Abstrak
Penelitian ini bertujuan untuk mengetahui gagasan pendidikan kewarganegaraan global serta peran pendidikan kewarganegaraan dalam membangun warga negara global. Penelitian ini merupakan penelitian studi literatur yang menganalisis berbagai teori tentang kewarganegaraan global dan pendidikan kewarganegaraan yang ada di Indonesia. Berdasarkan hasi penelitian menunjukkan bahwa Warga negara global merupakan bentuk pelaksanaan sistem kewarganegaraan yang mencangkup beberapa hak dan kewajiban dasar warga negara secara global. Warga negara global tentu harus disiapkan secara langsung khusunya pada jenjang sekolah dasar maupun sekolah menengah bahkan sampai perguruan tinggi. Melalui proses pendidikan kewarganegaraan yang diajarkan diharapkan mampu menyampaikan nilai-nilai dasar warga negara global dalam berkehidupan bermasyarakat dan bernegara. Sehingga akan mampu menyelesaikan berbagai permasalahan maupuan konflik serta isuisu yang terjadi secara global.
\end{abstract}

Kata kunci: Pendidikan Kewarganegaraan, Warga Negara Global

\section{THE RULE OF CIVIC EDUCATION IN BUILDING GLOBAL CITIZENS}

\begin{abstract}
The purpose of this study is to to find out the idea of global civic education as well as the role of civic education in building global citizenshi. This study is a study of literature that analyze various theories about global citizenship and civic education in Indonesia. Based on the results of research indicates that global citizen is a form of implementation of citizenship system that covers some basic rights and obligations of citizens global. Global citizens should be prepared directly at primary and secondary school levels. Through the process of citizenship education is expected to be able to convey the basic values of global citizens in berkehidupan social and state, So that will be able to solve various problems and conflicts and global issues.
\end{abstract}

Keywords: Civic Education, Global Citizens

Copyright (c) 2018, Citizenship Jurnal Pancasila dan Kewarganegaraan

Avaliable online at : http://e-journal.unipms.ac.id/index.php/citizenship

Print ISSN: 2302-433X Online ISSN : 2579-5740 


\section{PENDAHULUAN}

Perubahan yang terjadi di dunia saat ini sangatlah cepat, baik dari aspek teknologi, pendidikan, politik, hukum, maupaun ekonomi. Tentu hal ini akan berakibat pada perubahan tatanan dunia. Disisi lain tatanan-tatanan baru yang menjadi alternatif dalam menciptakan sistem global yang lebih baik belum terbentuk. Seperti halnya dampak dan pengaruh yang disebabkan oleh globalisasi. Hal tersebut tentu akan mengakibatkan lemahnya nilai-nilai sosial kemasyarakatan. Lemahnya nilai-nilai sosial kemasyarakatan akan menimbulkan krisis moneter yang dampaknya tentu akan terasa dalam kehidupan sehari-hari, sekaligus juga akan mempengarui karakter moral dan sikap perilaku manusia diberbagai belahan dunia seperti halnya negara berkembang yakni Indonesia (Syarbaini, 2006: 1).

Seiring dengan perkembangan teknologi dan informasi menjadikan masyarakat dunia menjadi lebih instan dan prakmatis yang kemudian menjadi sebuah kebudayaan yang sulit untuk dihilangkan. Pengaruh globalisasi akan berdampak secara luas bagi perkembangan warga negara secara global baik dari aspek keyakinan, norma-norma, prilaku, nilai-nilai bahkan aspek ekonomi dan perdangangan warga negara (Banks, 2008:132). Adanya krisis yang dialami negara tentu akan berdampak juga pada generasi muda. Muhammad Syaifudin \& Agus Satmoko (2014: 670) menyampaikan bahwa "Generasi muda tentu akan menjadi generasi penurus bangsa untuk memimpin dan membawa perubahan bagi bangsanya ke arah yang lebih baik". Perkembangan globalisasi yang bedampak pada perkembangan warga negara global tentu harus di selesaikan secara langsung baik dari peraturan pemerintah maupun sistem pendidikan yang dijalankan untuk menyiapkan warga negara global yang profesioanl dalam bermasyarakat dan bernegara.

Pendidikan di Indonesia sedang menghadapi masalah besar terkait dengan tantangan globalisasi yang semakin meluas di segala aspek kehidupan, termasuk dalam dunia pendidikan (Sutrisno \& Murdiono: 2017: 56). Oleh karena itu diperlukan adanya rekontruksi dalam dunia pendidikan untuk menyiapkan calon warga global. warga global merupakan bentuk pengembangan nilai-nilai dasar kemusiaan yang di jalankan secara global dalam bentuk pengembangan hak dan kewajiban warga negara untuk menjalankan tugas dan kewajibannya secara global. Pembentukan warga global tentu membutuhkan proses yang berkesinambungan dalam setiap jenjang pendidikan. Tentu hal ini harus dimulai dari jenjang sekolah dasar, sampai sekolah menengah bakan juga sampai pada perguruan tinggi.

Salah satu bentuk pengembangan muatan materi warga global dapat diajarkan atau disampaikan pada mata pelajaran Pendidikan Kewarganegaraan. Hal ini tentu mengingat bahwa materi Pendidikan Kewarganegaraan memiliki tujuan.

1)Menampilkan karakter yang mencerminkan penghayatan, pemahaman, dan pengamalan nilai dan moral Pancasila secara personal dan sosial; 2)Memiliki komitmen konstitusional yang ditopang oleh sikap positif dan pemahaman utuh tentang Undang-Undang Dasar Negara Republik Indonesia Tahun 1945; 3)Berpikir secara kritis, rasional, dan kreatif serta memiliki semangat kebangsaan serta cinta tanah air yang dijiwai oleh nilai-nilai Pancasila, Undang Undang Dasar Negara Republik Indonesia Tahun 1945, semangat Bhinneka Tunggal Ika, dan komitmen Negara Kesatuan Republik Indonesia, dan 4)Berpartisipasi secara aktif, cerdas, dan bertanggung jawab sebagai anggota masyarakat, tunas bangsa, dan warga negara sesuai dengan harkat dan martabatnya sebagai makhluk ciptaan Tuhan Yang Maha Esa yang hidup bersama dalam berbagai tatanan sosial Budaya. (PP Nomor 32 Tahun 2013)

Pendidikan Pancasila dan Kewarganegaraan memilik peran dan fungsi yang sangat penting dalam menanamkan nilainilai Ideologi Pancasila, yang didalamnya terdapat nilai-nilai dasar berprikemanusiaan dan berprikeadilan yang tentu menjadi dasar konsep warga global, hal tersebut tentu sebagaimana yang tercantu dalam tujuan pendidikan kewarganegaraan.

Pendidikan kewarganegaraan merupakan mata pelajaran wajib yang disiapkan untuk mencipatakan para warga negara yang aktif dalam menjalankan tugas dan tanggung jawab sebagai warga negara yang baik. Oleh karena intu Cogan 1999: 5) menyatakan bahwa pendidikan kewarganegaraan merupakan "education for citizenship is the large 


\section{Citizenship Jurnal Pancasila dan Kewarganegaraan Vol 6 No 1 April 2018, hal 41-51 \\ Avaliable online at : http://e-journal.unipma.ac.id/index.php/Citizenship \\ Print ISSN: $2302-433 X$ Online ISSN : 2579-5740}

overarching concept here while civic education is but one part, albeit a very important part, of one's developmen as citizen" Pendidikan kewarganegaraan memiliki peran yang penting dalam membentuk watak dan karakter warga negara agar mampu bersaing di era global. Pendidikan kewarganearaan senantiasa menjadi pengembang utama dalam meningkatkan sistem pendidikan nasional agar siap berpartisipasi menjadi warga negara global.

Adanya globalisasi tentu berdampak pada berbagai aspek kehidupan warga negara. Konsep warga negara global tentu menjadi isu yang terus berkembang bagi seluruh masyarakat di dunia. Warga negara global menutup setiap warga masyarkat memiliki peran yang sama dalam menjalankan hak dan kewajiban sebagai warga negara gelobal. Perkembangan kewarganegaraan yang diakibatkan adanya globalisasi tentu akan menjadi tuntutan bersama danya kesetaraan antar warga negara global dimana kebebasan dan kesetaraan menjadi tujuan utama. Konsep warga negara global menjadi hal utama yang diprioritaskan oleh negara-negara di penjuru dunia.

Secara umum masing-masing negara memiliki perbedaan dalam mengembangkan dan menjalankan tugas sebagai warga negara di masing-masing negara. Warga negara memiliki tugas dan tanggung jawab untuk bisa menjalankan tugasnya sebagai warga negara dengan baik. Namun demikin peran dari warga negara akan mengalami pergeseran secara mendasar oleh adanya pengembangan sistem globalisasi di setiap aspek kehidupan. Maka dari itu perlu disiapkan adanya calon warga negara yang siap menghadapai pergeseran tatanan kehidupan bernegara. Dengan demikian pendidikan dianggap menjadi lembaga yang penting untuk memahamkan konsep-konsep warga negara global melalu pendidikan kewarganegaraan di dalam kelas maupaun di luar kelas.

$$
\text { Melalui konsep Pendidikan }
$$

Kewarganegaraan global diharapkan warga negara mampu belajar secara luas tentang peran warga negara dunia untuk saling bekerjasama dan membangun kehidupan dunia bersama-sama dalam menyelesaikan berbagai konflik, isu, dan permasalahan lingkungaan atau perubahan iklim yang mengancam dunia. Pembelajaran Pendidikan Kewarganegaraan berwawasan global haruslah di ajarkan secara langsung pada jenjang sekolah dasar sampai sekolah menengah bahkan juga peruguran tinggi. Pendidikan kewarganegaraan global merupakan salah satu bentuk penanaman peran generasi muda agar bisa berwawasan global dalam upaya membangun kehidupan manusia yang lebih beradab. Melalui pendidikan kewarganegaraan yang berwawasan global akan menjadikan generasai muda mampu berfikir bagaimana bisa menjadi salah satu bagian dari warga negara global yang didalamya akan diberikan pengetahuan, ketrampilan serta karakter warga negara global yang bertanggung jawab. Hal ini sebagaimana dijelaskan oleh Osler dan Starkey (dalam Bourke et al., 2012: 163) bahwa pendidikan kewarganegaraan mencerminkan pendekatan maksimal yang bertujuan untuk memastikan peserta didik siap untuk mengambil peran sebagai warga global dewasa dan bertanggung jawab. Sekaitan dengan hal tersebut Dill, Jeffrey S (2012) juga menjelaskan bahwa Pendidikan Kewarganegaraan Global (Global Civic Education) merupakan bentuk reformasi pendidikan yang paling cepat di era saat ini. Pendidikan Kewarganegaraan global dianggap sebagai salah satu mata pelajaran yang dapat menyiapkan warga negara global untuk bisa memahami berbagai permasalahan global. Melalui Pendidikan Kewarganegaraan diharapkan dapat membutuk kepribadian utama warga negara muda yang cerdas, baik dan dapat diadalkan. Untuk bisa membentuk warga negara global yang cerdas, baik dan dapat diandalkan maka harus memiliki dua sifat yakni sikap yang peduli terhadap kondisi masyarakat dan sikap untuk bisa melakukan perubahan yang lebih baik. Sikap peduli yang dimaksud ini adalah bagaimana bisa mengembagkan kemampuan kepedulian tidak hanya pada lingkungan masyarakat akan tetapi lebih di tekankan pada konteks masyarakat global. Sedangkan sikap untuk bisa melakukan perubahan ini merupakan hal yang harus dilakukan dalam menuju kebaikan baik di dalam lingkungan masyarkaat bagsa maupun masyarakat secara global karena melalui perubahan ini akam mejadikan tolak ukur majunya perkembangan bangsa dan negara di dunia (Lickona, 2002)

Untuk menyiapkan warga negara yang siap menjadi salah satu bagian dari warga negara global tentu diperlukan upaya dan langkah- 


\section{Citizenship Jurnal Pancasila dan Kewarganegaraan Vol 6 No 1 April 2018, hal 41-51 \\ Avaliable online at : http://e-journal.unipma.ac.id/index.php/Citizenship \\ Print ISSN: 2302-433X Online ISSN : 2579-5740}

langkah strategis agar tercapi target tujuan pendidikan global yang berorienasi pada adanya kesamaan dalam menjalankan tugas, hak dan kewajiban warga negara secara global. Sehingga sangat diperlukan adanya pemahaman secara mendasar akan pentingnya gagasan pendidikan kewarganegaraan global dan peran pendidikan kewarganegaraan dalam membagun warga negara global yang memiliki kemampuan untuk saling menghormati dan menjunjung tinggi nilai-nilai dasar berkehidupan berbangsa dan benegara scara global..

\section{METODE}

\section{Jenis Penelitian}

Penelitian ini termasuk penelitian studi literatur dengan mencari referensi teori yang relefan dengan khasus atau permasalahan yang ditemukan. Referensi teori yang diperoleh dengan jalan penelitian tudi literatur dijadikan sebagai acuan untuk mengembangakan teori konsep baru ketika praktek penelitian di lapangan

\section{Waktu dan Tempat Penelitian}

Penelitian ini dilakukan pada sekolah menengah atas di Kabupaten Ponorogo di semester Ganjil pada tahun ajaran 2018/2019.

\section{Subjek Penelitian}

Subjek penelitian ini terdiri dari Guru Mata Pelajaran Pendidikan Pancasila dan Kewarganegaraan di sekolah menengah atas, buku referensi tentang Global Civic Education, serta hasil penelitian tentang warga negara global dan pendidikan kewarganegaraan global. sedangkan objek dalam penelitian ini adalah mata pelajaran pendidikan kewarganegaraan yang di terapkan di jenjang sekolah menegah atas.

\section{Prosedur}

Prosedur dalam penelitian ini dengan menganalisis hasil penelitian tentang pendidikan kewarganegaraan global dan warga negara global secera teori kemudian direkontruksikan dengan berbagai teori pembelajaran pada Pendidikan Kewarganegaraan yang ada di Sekolah Menengah Atas. Setelah terbentuk hipotesis dari rekontruksi pertanyaan penelitian, kemudian di aktualisasikan dalam bentuk kajian teori baru yang membahas tentang peran pendidikan kewarganegaraan dalam membangun warga negara global.

\section{Data, Intrumen, dan Teknik Pengumpulan Data}

Instrumen penelitian yang digunakan dalam penelitian ini adalah observasi, studi literatur dan dokumentasi sedangkan bentuk pengumpulan data dari penelitian ini dengan menganalisis hasil data dari observasi di sekolah menengah atas khusunya pada mata pelajaran Pendidikan Pancasila dan Kewarganegaraann serta pendidik. Adapun hasil instrumen dari studi literarut dan domunetasi di analisis dalam bentuk kajian secara teoritis untuk diambil kesimpulan secara umum dan diaktualisasikan dalam bentuk konsep pembelajaran.

\section{Teknik Analisis Data}

Teknik analisis data yang digunakan dengan metode analisis diskiptif yakni dengan menggambarkan atau menganalisis suatu hasil penelitian tetapi tidak digunakan untuk membuat kesimpulan akan tetapi diaktualisasikan dalam bentuk pengembangan teori, implikasi, dan saran.

\section{HASIL PENELITIAN DAN PEMBAHASAN}

\section{Hakikat Warga Negara Global (Global Citizenry)}

Globalisasi di era saat ini tentu membawa perkembangan yang sangat signifikan dalam berbagai bidang kehidupan manusia. Globalisasi dapat dimaknai dengan berbagai pemahaman tergantung dari sudat mana memahami makna globalisasi. Banyak perdebatan yang membahas tentang adanya dampak globalisasi khusunya pada negara berkembang. Adanya globalisasi akan menjadikan negara tersebut justru akan menjadi negara yang kaya semakin kaya, atau justur menjadikan negara yang miskan akan semakian miskin dalam menghadapi era globalisasi.

Adanya globalisasi juga berdampak pada kondisi sosial kemasyarakatan warga negara. kondisi sosial kemasarakatan dalam globalisasi terikat oleh tiga dimensi dalam globalisasi yakni 
ekonomi, politik dan kultural. Globaliasi ekonomi berdampak pada adanya perkembangan pada berbagai kondisi pasar-pasar ekonomi global, perdagangan bebas, dan pertukaran barang dan jasa. Globalisasi politik memiliki peran pada globaliasi dunia yakni terjadinya dominasi peran organisasi internasional dalam mengatur negara di bawah kendali PBB dan Uni Eropa yang mengakibatkan munculnya politik Global. Globalisasi kultural merupakan perkembangan kondisi sosial masyarakat pada ranah teknologi dan informasi secara global, model globalisasi ini menjadi konsep pemahaman tentang warga negara global (Melcom waters: 1995).

Konsep warga negara global ini tentu bukan menjadi hal baru. munculnya pemahaman tentang warga negara global sudah mucul sejak zaman yunani kuno tepatnya pada abad ke 4 SM. Munculnya konsepsi akan warga negara dunia ini berawa dari ketidak terimaan akan kesetian publik warga negara yang dikemukakan oleh salah satu filsuf Diogenes. Kemudian Linklater (2002) menyatakan adanya gogasan tersubut menjadi rujukan untuk mengkritisi negara terkait adanya bentuk kedaulatan secara universal. Dengan tujuan dapat mewujudkan kehidupan warga negara dunia yang adil, makmur dan damai.

Secara umum warga negara global dapat diartikan sebagai pemahaman akan tanggung jawab warga negara untuk memenuhi persyaratan institusional dan kultural demi kebaikan yang lebih besar bagi masyarakat dunia. Menurut Beth salah seorang guru studi sosial di Hickory High School (dalam Dill, Jeffrey S, 2012) mengungkapkan bahwa warga negara global adalah seseorang yang berakar dalam identitas kebangsaannya, tatapi mereka memiliki kesadaran yang lebih besar dari pada itu yakni menghargai berbagai keberagaman budaya-budaya, sikap toleransi terhadap keyakinan dan kepercayaan lain serta melihat berbagai isu-isu global sebagai kajian utama dari pada batasa-batasan bangsanya sendiri.

Warga negara global menitik beratkan pada peran warga negara global dalam menjalankan hak dan kewajiban secara global. Konsep warga negara global cenderung megembangkan istilah dalam kewarganegaraan global yang dalam hal ini menurut Bringham $\begin{array}{llr}\text { (dalam Zahabioum, } & \text { Yousefy, }\end{array}$ Yarmohammadian, Keshtiaray, 2012) of understanding - how the world works, links between our own lives and those of people throughout the world". Kewarganegaraan global membahas tentang peran dan tanggung jawab manusi dalam memahami, melihat dan bertindak dalam kondisi dunia kerja, serta hubungan antar kehidupan manusia secara individu dan warga negara di seluruh dunia.

Perkembangan warga negara global terdapat berbagai kritikan dari beberapa pihak selain adanya yang mendukung tentang konsep warga negara global. Dalam hal ini Michael Walzer menjelaskan bahwa dalam memahami makna warga negara global harus memahami tentang apa warga negera bangsa dan warga negara global. Seorang warga negara global tidak bisa diartikan sebagai warga negara global lantaran ada kebutuhan hak dan kewajiban yang harus dipenui dari warga negara bangsa. Oleh karena konsepsi tentang warga negara dunia hurus diperhitungkan secara matang kalau tidak hal ini justru malah akan menjadi alat politik yang dibalut dalam makna secara unviersal. Hal ini harus bisa disikapi dengan bijak bahwa konsepsi warga negara dunia akan dijadikan sebagai alat kepentingan politik untuk imprealisme budaya bangsa lain atau malah justur bisa digunakan sebagai tren gerakan secara universal bangsa-bangsa untuk mengembankan bentuk solidaritas sosial antar umut manusia dalam menyelesaikan permasalahan-permasalahan dunia di era globalisasi demi terwujudnya kehidupan dunia yang adil dan damai.

Sebagai salah satu komponen dari warga negara bangsa maka secara umum manusia harus bisa menempatkan posisinya pada tataran kapan menjadi warga negara bangsa dan kapan menjadi warga negara global. Tentu hal ini tidak semata-mata sebagai perwujudan dari paham tentang warga negara global akan tetapi satu hal yang lebih penting yakni bisa menjadi warga negara yang memiliki perspektif global untuk bisa bersama-sama menyelesaikan permasalahan isu-usu global seta konflik-konflik yang terjadi (Wahab AA \& sapriya, 2011). Dengan demikian perlu adanya persiapan sejak dini agar persepsi ini bisa ditransformasikan melalui pendidikan 
yang berkelanjutan di jenjang sekolah baik formal maupun non formal. Hal ini bisa dilakukan pada peserta didik dalam setiap proses pembelajaran di dalam kelas maupun di luar kelas. Adapun mata pelajaran yang bisa menumbuhkan pemahaman dan kemampuan untuk bisa berpartisipasi dalam permasalahan global yakni Pendidikan Kewarganegaraan (Civic Education).

\section{Gagasan Pendidikan Kewarganegaraan Global}

Pendidikan kewarganegaraan tentu menjadi tujuan utama dalam mengembangkan sikap dan keterampilan warga negara dalam menjalankan hak dan kewajiban sebagai warga negara. Warga negara yang memiliki karakter cerdas, terampil dan berkarakter, tentu hal ini berkaitan dengan amanat pancasila dan Undangundang Dasar 1945. Dalam hal ini Sumantri (2001: 59) menjelaskan bahwa Pendidikan Kewarganegaraan dirumuskan sebagai suatu seleksi dan adaptasi dari lintas disiplin ilmuilmu sosil, ilmu kewarganegaraan, humniora, dan kegiatan dasar manusia yang diorganisasikan dan disajikan secara psikologis dan ilmuah untuk ikut mencapai salah atau tujuan pendidikan. Sependapat dengan pendapatnya Sutrisno (2017: 168) bahwa Pendidikan Kewarganegaraan merupakan pendidikan yang berfungsi untuk membangun kesadaran warga negara dalam menjalankan hak dan kewajiban sebagai warga negara dalam upaya membentuk identitas terhadap warga negara bagi suatu bangsa.

Pendidikan kewarganegaraan berupaya membentuk warga negara yang cerdas dan baik sebagai warga negara hal ini sebagimana di jelaskan David Kerr dalam Winarno Citizenship education dalam arti luas ialah "proces to encompass the preparation of young people for their roles and responibilities as citizen and in particular, the role of education (through schooling, teaching, and learning) in that prepatory process." Dalam pengertian tersebut dikatakan bahwa Pendidikan Kewarganegaraan memiliki arti khusus sebagai proses pendidikan yang diwujudkan guna menyiapkan generasi mudanya akan hak-hak, peran maupun tanggungjawabnya sebagai warga negara (Winarno, 2013: 5). Dalam kajian sosial pendidikan kewarganegaraan merupakan salah satu bidang ke ilmuan yang bersifat multidimensional, hal ini ditinjau dari tinjauan pedagogik, menyatakan bahwa pendidikan kewarganegaraan meliputi program kurikuler dan aktivitas sosial kultural. Dengan demikian maka sifat multidimensionalnya dari pendidikan kewarganegaraan dapat disikapi sebagai pendidikan nilai dan moral, pendidikan kemasyarakatan, pendidikan kebangsaaan, pendidikan politik, pendidikan hukum, dan pendidikan demokrasi.

Konsep warga negara gelobal tentu tidak bisa dilepaskan dari pendidikan kewarganegaraan hal ini mengingat bahwa muatan nilai-nilai dasar warga negara global ada dan dikembangkan dalam pendidikan kewarganegaraan. Dengan demikian gagasan warga negara gelobal menjadi tujuan utama dalam pendidikan kewarganegaraan untuk menumbuhkan dan mengembangkan nilai-nilai dasar warga negara dunia yang dijalankan melalu peran akan pelaksanaan akan hak dan kewajiban yang harus dilakukan oleh setiap warga negara dunia.

Adanya konsep warga negara global tentu tidak bisa dipisahkan dengan adanya arus globalisasi yang berkembang saat ini. Persamaan hak dan kewajiban warga negara dalam mejalankan tugas dan kewajiban sebagai warga negara yang tidak di batasi oleh wilayah teritorial negara merupakan konsep dasar warga negara global (Gerzon, 2010: 78). Berbagai fonomena permasalahan global tentang warga negara menuntut adanya penyelesaian secara bersama yang diataru dalam peraturan hukum secara jelas atas dasar persamamaan sebagai salah satu warga dunia. Bentuk kerjasa sama dalam berpartisipasi warga negara global merupakan contoh positif warga negara dalam upaya membangun tatanan dunia Internasional yang baik. Warga negara dalam prespekif global akan selalu menjunjung nilai-nilai dasar keadilan, kemanusian, kepedulian dalam bentuk satu kesatuan masyarakat global.

Warga negara global memiliki peran penting dalam mejadikan seluruh bangsa-bangsa di berbagai negara memiliki rasa persatuan dan kesatuan dalam membangun dunia yang lebih baik. Rasa persatuan dan kesatuan akan muncul 


\section{Citizenship Jurnal Pancasila dan Kewarganegaraan Vol 6 No 1 April 2018, hal 41-51 \\ Avaliable online at : http://e-journal.unipma.ac.id/index.php/Citizenship \\ Print ISSN: 2302-433X Online ISSN : 2579-5740}

dengan adanya permasalahan-permasalahan global. Hater (2004) menyatakan bahwa tingkat persatuan dan kesatuan berbagai bangsa akan terbentuk manakala ada permasalahan yang mencakup kepentingan umum yang berhubungan dengan hak dan kewajiban warga negara globel yang pada akhirnya akan mempengarui orang-orang untuk mendeklarasikan diri sebagai salah satu bagian dari warga negara global sebagai kekuatan untuk menigkatkan kepentingan secara global.

Pendidikan kewarganegaraan global pada dasarnya memiliki tujuan yang sangat baik untuk menciptakan adanya persamaan persepsi akan adanya tugas, hak dan kewajiban warga negara dalam menjalankan tugas menjadi warga negara yang baik dan tidak mebedakan adanya persamaan ras, suku, budaya, agama maupun kelompok yang sama-sama memiliki hak asasi. Dengan demikian tidak adanya perbedaan antara warga negara satu dengan warga negara yang lain. Pembedanya hanya terletak pada hak dasar yang melekat pada negara dimana dia tinggal. Hal ini inilah yang secara umum disebut dengan kesamaan hak diantar seluruh umat manusia. Sebagaiman dijelaskan oleh Linklater, A (2002: 325) bahwa pendidikan kewarganegaraan global akan menjadi lebih bermakna apabila hak dan kewajiban warga negara secara global dapat disatukan dalam bentuk hukum yang diatur secara Internasioal. Dengan catatan setiap warga negara mampu memiliki persamaan rasa persatuan dan kesatuan dalam menyelesaiakan dan menjaga kestabilan internasional secara bersama-sama dan tidak membedakan adanya perbedaan yang ada.

Gagasan akan kewarganegaraan global tentu menjadi satu alternatif untuk menyatukan persepsi akan penyelesaian setiap permasalahan Internasional baik dari aspek bindang ekonomi, politik, kesehatan, bahkan lingkunga hidup yang pada faktanya secara terus menurus mengancam adanya kestabilan internasional di berbagai negara. Dengan demikian warga negara global harus dituntut untuk bisa berpartisipasi secara aktif. Konsep nilai-nilai dasar dalam perkembangan sosial kebudayaan suatu negara tidak bisa hilang karena adanya bentuk persamaan persepsi sebagai salah satu bagian dari warga negara global. Akan tetapi persepsi akan persamaan warga negara global akan menjadi acuan setiap warga negara agar mampu berkontribusi dalam mejunjung tinggi nilai persatuan dan kesatuan yang diatur dalam konsep berperikemusian yang adil dan beradab.

Persepsi akan waraga negara global dalam pendidikan kewarganegaraan akan menjadi pedoman warga negara untuk bisa berpartisipasi menyelesaiakan permasalahan-permasalahan global yang terjadi. Bentuk partisipasi seperti ini yang akan dijadikan acuan dalam pendidikan kewarganegaraan di setiap negara. Melalu pendidikan kewarganegaraan secara global diharapkan mampu menjadikan warga negara menyiapkan diri untuk bisa berpartisipasi aktif dan berkerjasama dalam membangun tata kehidupan dunia Internasional yang selalu berlandaskan akan nilai-nilai nasionalisme. Hal tersebut tentu sebagimana dijelaskan oleh Cogen (1998:2-3) bahwa Pendidikan kewarganegaraan global memiliki beberapa komponen pokok yaitu "the enjoyment of certains rights: the fulfilment of corresponding obligations: a degree of interst and involvement in public affairs and an acceptance of basic societal values". Komponen ini akan menjadi dasar kepribadian bangsa dalam membentuk warga negara global yang tetap berlandaskan akan nilai-nilai nasionalisme negara dan menjunjung tinggi adanya rasa persatuan dan kesatuan warga negara secara gelobal untuk membagun kehidupan internasional yang berkemajuan.

\section{Peran Pendidikan Kewarganegaraan Dalam Membangun Warga Negara Global}

Pendidikan Kewarganegaraan secara umum memberi kontribusi yang sangat besar untuk menyelesaikan berbagai permasalah global. Pada dasarnya manusia akan selalu berhubungan satu sama lain, karena pada hakikatnya manusia bisa diartikan sebagai makhluk sosial yang selalu membutuhkan bantuan orang lain. Begitupun konsep warga negara bangsa, setiap negara memiliki permasalahan secara universal tentang negara dan bansa, yang tentu dalam hal ini membutuhkan bantuan dan kerjasama dari bangsa dan negara lain di dunia. maka dari itu konsepsi Pendidikan Kewarganegaraan muncul untuk memberikan pengalaman dan pendidikan bagi warga negara muda di berbagai negara untuk bisa menyelesaikan permasalahanpermasalahan global dan bisa bekerjama untuk 
membangun warga negara global melalu proses pembelajaran pada mata pelajaran Pendidikan Kewarganegaraan baik di lingkup pendidikan formal, nonformal maupun informal

Pendidikan Kewarganegaraan secara umum memberikan kontribusi untuk membina dan mengembangkan karakter warga negara yang cerdas dan baik. Hal tersebut tentu sudah menjadi bagian dari ide, instrumentasi dan praksis dalam pendidikan nasional di Indonesia, sebagaimana dijelaskan oleh Winataputra (2015) bahwa keberadaannya sudah terwujud dalam lima status yakni pertama, sebagai mata pelajaran yang di kembangkan dan ada pada kurikulum sekolah. Kedua, masuk pada ranah program mata kuliah wajib (MKU) di kurikulum perguruan tinggi. Ketiga, masuk pada ranah cabang pendidikan disiplin ilmu sosial dalam kerangka program pendidikan guru yang dibina dan dikembangkan oleh lembaga program studi Pendidikan Kewarganegaraan pada lembaga pendidikan tenaga kependidikan (LPTK). Keempat, masuk pada ranah program pendidikan politik yang dikemas dalam penataran P4 di era tahun 1970-1990-an atau bentuk sejenisnya yang dikelola dan di kembangkan serta di atur oleh Pemerintah. Kelima, sebagai kerangka konseptual, dalam bentuk pemikiran individual atau kelompok pakar terkait yang di kembangkan sebagai landasan dan kerangka berfikir tentang pendidikan kewarganegaraan.

Pendidikan kewarganegaraan merupakan pendidikan yang bisa mengarahkan pembentukan watak dan peserta didik untuk memiliki kesadaran sebagai salah satu warga negara global. Pendidikan Kewaarganegaraan tentu menjadi pilihan untuk melatih sikap, pengetahuan dan keterampilan warga negara untuk bisa berpartisipasa dalam menyelesaiakn permasalahan, konflik, dan isu-isu global yang terjadi melalui pola pembelajaran yang diterapkan. Sekait dengan hal tersebut Dill, Jeffrey S (2012) menjelaskan bahwa Pendidikan Kewarganegaraan Global (Global Civic Education) merupakan bentuk reformasi pendidikan yang paling cepat di era saat ini. Pendidikan Kewarganegaraan global dianggap sebagai salah satu mata pelajaran yang dapat menyiapkan warga negara global untuk bisa memahami berbagai permasalahan global.
Melalui Pendidikan Kewarganegaraan diharapkan dapat membutuk kepribadian utama warga negara muda yang cerdas, baik dan dapat diadalkan. Untuk bisa membentuk warga negara global yang cerdas, baik dan dapat diandalkan maka harus memiliki dua sifat yakni sikap yang peduli terhadap kondisi masyarakat dan sikap untuk bisa melakukan perubahan yang lebih baik. Sikap peduli yang dimaksud ini adalah bagaimana bisa mengembagkan kemampuan kepedulian tidak hanya pada lingkungan masyarakat akan tetapi lebih di tekankan pada konteks masyarakat global. Sedangkan sikap untuk bisa melakukan perubahan ini merupakan hal yang harus dilakukan dalam menuju kebaikan baik di dalam lingkungan masyarkaat bagsa maupun masyarakat secara global karena melalui perubahan ini akam mejadikan tolak ukur majunya perkembangan bangsa dan negara di dunia (Lickona, 2013). Tentu sikap seperti ini dapat dibentuk dengan proses pendidikan dan pembelajaran khususnya pada mata pelajaran Pendidikan Kewaarganegaraan. Proses pembelajaran Pendidikan Kewarganegaraan bisa menggunakan berbagai pendekatan, strategi, model, media, dan sumber belajar yang mampu mengajarkan pada peserta didik, khusunya pada tarap kemampuan pengembangan sikap, pengetahuan dan keterampilan tentang rasa kepedulian antar umat manusia di dunia sebagai salah satu bagian dari warga negara global.

Agar Pendidikan Kewarganegaraan ini mampu membangun warga negara global yang memiliki kemamuan untuk dapat berpartisipasi dalam masyarakat global maka ada beberapa peran yang bisa dilakukan. Pertama. Pendidik harus bisa meningkatkan kemampuan sikap, pengetahuan dan keterampilan peserta didik secara universal. Sebagaimana dijelaskan oleh Dill, Jeffery (2012) bahwa pendidik/guru di abad ke-21 sedang berusaha untuk membuat peserta didiknya masuk dalam warga negara global. Adapun kemampuan tersebut di bisa diterapkan melalui pengembangan kompetensi peserta didik tentang kesadaran hidup dalam dunia yang lebih adil, toleran dan damai. Kompetensi ini menurut Richard Remy (dikutip dalam Wahab AA dan Sapriya, 2011) dapat dikembangkan melalui beberapa prosedur yang meliputi, "1) Acquiring and Using Information, 2) Assessing Involvement, 3) Making Decision, 


\section{Citizenship Jurnal Pancasila dan Kewarganegaraan Vol 6 No 1 April 2018, hal 41-51 \\ Avaliable online at : http://e-journal.unipma.ac.id/index.php/Citizenship Print ISSN: 2302-433X Online ISSN : 2579-5740}

4) Making Judgement, 5) Communication 6) Cooperating 7) Promoting Interest".

Sedangkan peran kedua yakni penguatan nilai-nilai komitmen moral serta empati diluar kepentingan individu dan kelompok. Penguatan nilai moral dan empati diluar kepentingan individu dan kelompok ini merupakan kunci utama dalam padangan konsep warga negara global. artinya warga negara dituntut untuk meminimalisir adanya kepentingan pribadi atau kelompok di atas kepentingan secara umum. Maka dari itu sangat dipelukan adanya pemahamn secara umum bagi warga negara muda khususnya pada jenjang pendidikan kewarganegaraan untuk bisa meingkatkan kemampuan sikap, pengetahuan dan keterampilan warga negara yang menurut Merryfield (dikutif dalam Surya Dharma, 2016) meliputi 1) menjunjung tinggi nilai keberegaman dalam setiap proses pembelajaran, 2) menumbuhkan persepsi akan pentingnya ikatan sosial antar masyarakat yakni dunia merupakan satu kesatuan yang saling ketergantungan dan terikat satu sama lain, 3) hubungan antar manusia yang selalu di pengaruhi adanya hubungan dan organisasi global di berbagai dunia.

Peran tersebut tentu harus di dukung dengan mekanisme dan proses pembelajaran yang terintegrasi. Integrasi ini bisa diterapkan melalui konsep pendekatan pembelajaran (learing approach) strategi (teaching strategy) dan model pembelajaran (model of teaching). Ketiga konsep integrasi pembelajaran dapat dikembangkan dalam bentuk pendidikan otentik. Pendidikan otentik merupakan bentuk pendidikan yang menerapkan psikologi humanistik yang menekankan pada pendidikan untuk membangun manusia seutuhnya. Pendidikan otentik menurut Gulikers, Bastiaen dan kirchner (dikutip dalam Winataputra, 2015: 395) menjelaskan bahwa "authentic education dengan menempatkan konsep authentic learing, authentic instruction, and authentic assessment dalam paradikma authentic education". Pendidikan otentik menekankan pada proses pengajaran yang menitik beratkan pada keterhubungan antara pembelajaran, proses belajar dan penilaian hasil belajar secara keseluruhan.
Pendidikan Kewarganegaraan tentu menjadi poros utama dalam menyiapkan warga negara global di era globalisasi yang terus berkembang. Warga negara global memiliki beberapa karakteristik yang harus nampak, dan hal ini harus disapkan pada setiap proses pembelajaran pada Pendidikan Kewarganegaraan. Karakteristik tersebut menurut John C. Cogan, (1999) terdiri dari beberapa kemampuan yakni 1) Kemampuan mengenal dan mendekati masalah sebagai warga masyarakat global, 2) Kemampuan bekerjasama dengan orang lain dan memikul tanggung jawab atas peran atau kewajibannya dalammasyarakat, 3) Kemampuan untuk memahami, menerima, dan menghormati perbedaan-perbedaan budaya, 4) Kemampuan berpikir kritis dan sistematism 5) Kemampuan menyelesaikan konflik dengan cara damai tanpa kekerasan, 6) Kemampuan mengubah gaya hidup dan pola makanan pokok yang sudah biasa guna melindungi lingkungan, 7) Kemampuan untuk memiliki kepekaan terhadap dan mempertahankan hak asasi manusia (seperti hak kaum wanita, minoritas etnis, dsb), 8) Kemapuan dan kemampuan berpartisipasi dalam kehidupan politik pada tingkatan pemerintahan lokal, nasional, dan internasional.

Karakterisitk warga negara global inilah yang harus terus dikembangkan dan ditingkatkan pada setiap proses pembelajaran Pendidikan Kewarganegaraan di berbagai jenjang pendidikan, sehingga akan mempu menyiapkan calon warga negara global yang dapat berpartisipasi secara global dalam menyelesaikan berbagai permasalahan, konflik dan isu-isu global secara bersama sabagai salah satu kewajiban warga negara global. Maka akan terciptanya tatanan kehidupan kemanusiaan yang beradab adil dan makmur dalam lingkup masyarakat global.

\section{SIMPULAN DAN SARAN}

\section{Simpulan}

Pendidikan Kewarganegaraan dapat membangun konsep warga negara global apabila proses pembelajaran yang dilakukan perorientasi pada pengembangan kemampuan sikap, pengetahuan dan keterampilan dalam 


\section{Citizenship Jurnal Pancasila dan Kewarganegaraan Vol 6 No 1 April 2018, hal 41-51 \\ Avaliable online at : http://e-journal.unipma.ac.id/index.php/Citizenship Print ISSN: 2302-433X Online ISSN : 2579-5740}

menyelesaikan berbagai permasalah, konflik dan isu-isu global berbasis pendidikan otentik dengan penerapan strategi, pendekatan dan model pembelajaran yang terintegrasi. Hal tersebut merupakan salah satu bentuk pengamalan nilai-nilai dasar proses pembelajaran Pendidikan Kewarganegaraan untuk membagun karakter warga negara global yang baik cerdas dan dapat diandalkan..

\section{Saran}

Pembentukan pendidikan kewarganegaraan global tentu harus dilakukan sejak dini namun demikian pada jenjang sekolah menengah atas merupakan bentuk proses pembelajaran ideal untuk menerapkan porses pembelajaran pendidikan kewarganegaraan global karena pada jenjang sekolah menengah atas peserta didik mampu mengapresiasikan tingkat kemampuan kongnitif, efektif dan psikomotorik secara maksimal. Agar Pendidikan Kewarganegaraan ini mampu membangun warga negara global yang dapat berpartisipasi dalam masyarakat global dalam menyelesaikan berbagai permasalahan lingkungan global maka Pendidik harus bisa meningkatkan kemampuan sikap, pengetahuan dan keterampilan peserta didik secara universal. Adapun kemampuan tersebut bisa diterapkan melalui pengembangan kompetensi peserta didik tentang kesadaran hidup dalam dunia yang lebih adil, toleran dan damai

\section{DAFTAR PUSTAKA}

Banks, J. A. 2008. "Diversity, Group Identity, and Citizenship Education in A Global Age", dalam Educational Researcher, 37 (3), hlm. 129-139

Bourke, L., Bamber, P., dan Lyons, M. 2012. "Global Citizens: Who Are They?", dalam Education, Citizenship and Social Justice, 7 (2), hlm. 161-174

Cogan, I. J, (1999). Developing the Civil Society: The Role of Civic Education. Bandung: CICED
Dill Jefferey, S. (2012). The Moral Education of Global Citizenship. Global Sociaty. pp. 541-456. DOI: 10.1007/s12115-012-9599-8.

Gerzon, M. (2010). American Citizen, Global Citizen: How Expanding Our Identities Makes Us Safer, Stronger, Wiser, And Builds a Batter World. United State of America: Library of Congres Cataloging. Book@SpiritScoper.com

Hater. (2004). A. Brief History of Citizenship. Pp. 105-113. Word Citizenship. Edinburgh University Press

Lickona T. (2002). Education For Character: Mendidikkn untuk Membentuk Karakter: Bagaimana Sekolah dapat Mengajarkan Sikap Hormat dan Tanggung Jawab. Jakarta: Bumi Aksara.

Linkalter, A. (2002). "Cosmopolitin Citizenship” pp. 317-331 in Isin, F. E and B.S. Turner. Handbook of Ctitizenship. London: SAGE Publication

Muhammad Syaifudin \& Agus Satmoko. (2014). Kontribusi Pendidikan Pancasila dan Kewarganegaraan (PPKn) dalam Pembentukan Perilaku siswa SMA Negari 19 Surabaya. Kajian Moral dan Kewarganegaraan Volume 2 Nomor 2.

Republik Indonesia. (2013). Peraturan Pemerintah Nomor 32 Tahun 2013 Tentang Tujuan Pendidikan Pancasila dan Kewarganegaraan.

Shahla Zahabioun, Alireza Yousefy, Mohammad H Yarmohammadian \& Narges Keshtiaray. (2013). Global 
Citizenship Jurnal Pancasila dan Kewarganegaraan Vol 6 No 1 April 2018, hal 41-51

Avaliable online at : http://e-journal.unipma.ac.id/index.php/Citizenship

Print ISSN: 2302-433X Online ISSN : 2579-5740

Citizenship Education and Its Implications for Curriculum Goals at the Age of Globalization. International Education Studies. pp.195-206. DOI: 10.5539/ies.v6n1p195

Suemantri. 2001. Pendidikan

Kewarganegaraan. Jakarta: PT. Bumi Aksara.

Sutrisno. (2017). Implementasi pendidikan antikorupsi pada mata pelajaran PPKn berbasis project citizen di Sekolah Menengah Atas. Jurnal Civics, 14 (2), pp. 166-175. DOI:

10.21831/civics.v14i2.15664

Surya Dharma. (2016). Teori Sosial dan Kewarganegaraan. Bandung: Widya Aksara Press

Sutrisno \& Murdiono. (2017). Pengembangan Modul Pendidikan Anti Korupsi Pada Mata Pelajaran Pendidikan Pancasila Dan Kewarganegaraan Untuk Kelas X
Sekolah Menengah Atas. Harmoni Sosial: Jurnal Pendidikan IPS. 4(1), pp. 55-66. DOI: 10.21831/hsjpi.v4i1.9789

Syarbaini, Syahrial, dkk. 2006. Membangun Karakter dan Kepribadian melalui Pendidikan Kewarganegaraan. Jakarta : UIEU - University Press

Udin S. Winataputra. (2015). Pendidikan Kewarganegaraan Refleksi Historis Epistimologi dan Rekonstruksi untuk Masa Depan. Banten: Universitas Terbuka.

Wahab, AA dan Sapriya. (2011). Teori dan Landasan Pendidikan Kewarganegaraan. Bandung: Alfabeta.

Waters, Malcolm. (1995). Globalization. London: Routladge

Winarno. (2013). Pembelajaran Pendidikan Kewarganegaraan: Isi, Strategi, dan Penilaian. Jakarta: PT Bumi Aksara. 